Final version:

Lindgreen, A., Swaen, V., and Johnston, W.J. (2009), "The supporting function of marketing in corporate social responsibility", Corporate Reputation Review, Vol. 12, No. 2, pp. 120-139. (ISSN 1363-3589)

For full article, please contact LindgreenA@ cardiff.ac.uk

\title{
The Supporting Function of Marketing in Corporate Social Responsibility
}

\author{
Adam Lindgreen, ${ }^{1}$ Hull University Business School
}

Valérie Swaen, ${ }^{2}$ Université catholique de Louvain and IESEG School of Management Wesley Johnston, ${ }^{3}$ Georgia State University

${ }^{1}$ Dr. Adam Lindgreen, Professor of Strategic Marketing, Department of Marketing and Business Strategy, Hull University Business School, Hull HU6 7RX, the U.K. E-mail: a.lindgreen@hull.ac.uk. Telephone: + 441482463096 .

${ }^{2}$ Dr. Valérie Swaen, Université catholique de Louvain, Louvain School of Management, Place des Doyens 1, 1348 Louvain-la-Neuve, Belgium. E-mail: valerie.swaen@uclouvain.be. Telephone: + 32 1047 9156. She is a part-time assistant professor with the IESEG School of Management.

${ }^{3}$ Dr. Wesley J. Johnston, Professor of Marketing, J. Mack Robinson College of Business, Georgia State University, Atlanta, GA 30303-3083, the U.S.A. E-mail: mktwjj@langate.gsu.edu. Telephone: + 14046514184. 


\title{
The Supporting Function of Marketing in Corporate Social Responsibility
}

\begin{abstract}
The authors investigate both marketing and corporate social responsibility (CSR) practices, develop an instrument to measure those practices, and apply it to a survey of 441 U.S. organizations. The survey identifies four reliable types of marketing practices and five reliable dimensions of CSR practices. Furthermore, this study confirms the proposition that CSR practices are more prevalent in organizations that employ relational marketing practices; all types of CSR practices are positively influenced by one or more types of relational marketing practices, but transaction marketing specifically supports CSR practices related to customers, suppliers, and investors. Finally, by reaching out to its stakeholders, an organization can increase its revenues and profits, which in turn improves its chance of surviving in the long run.
\end{abstract}

KEYWORDS: corporate social responsibility, CSR, marketing, U.S. organizations, PLS. 


\section{The Supporting Function of Marketing in Corporate Social Responsibility}

\section{INTRODUCTION}

Social responsibility ranks high on the corporate agenda (Dunphy et al., 2003; Greenfield, 2004; McWilliams et al., 2006; Pearce and Doh, 2005) in an environment in which organizations must deliver profits to shareholders but also frequently are subject to broader stakeholder interests and the need to demonstrate a balanced business perspective (Kotler and Lee, 2005; Maignan and Ralston, 2002). Theorists and practitioners alike have come to believe that "not only is doing good the right thing to do, but it also leads to doing better" (Bhattacharya and Sen, 2004: 9; see also Williams and Barett, 2000); as a result, organizations increasingly define their roles in society and apply social and ethical standards to their business (Carroll, 1979; Lichtenstein et al., 2004; Maignan et al., 1999).

Yet even as CSR has moved from ideology to reality, its study remains embryonic (Bhattacharya and Sen, 2004; Maignan and Ferrell, 2001; Matten et al., 2003), making CSR "is one of the fastest growing - and least understood-areas of reputation management" (Bertels and Peloza, 2008: 57). Several identified research lacunae (Lindgreen et al., 2008) include the following: First, CSR has developed under the influence of various theories, thus impeding a full understanding of what CSR should comprise and hindering its further theoretical development (McWilliams et al., 2002; Snider et al., 2003). Second, no studies address how organizations might emphasize different aspects of CSR. Consequently, theorists are confused about the actual use of CSR, and practitioners lack guidance about how to formulate and deploy CSR (Bhattacharya and Sen, 2004; Smith, 2003). Third, there is a need to measure returns 
on CSR (Bhattacharya and Sen, 2004), because past studies have not demonstrated an unequivocal relationship between CSR and economic performance (Aupperle et al., 1985; Griffin and Mahon, 1997). We address these three critical issues by surveying and reporting on how 441 U.S. organizations design and implement actual CSR programs; in particular, we consider the supporting role of marketing.

We structure the remainder of this article as follows: First, we provide a literature review, which we use to develop a theoretical framework. Second, we describe the methodology, and third, we present and discuss the results of our survey of U.S. organizations. Fourth and finally, we identify our study's contributions and managerial implications, as well as some limitations, and suggest avenues for further research.

\section{LITERATURE REVIEW AND THEORETICAL FRAMEWORK}

In this section, we first consider CSR and the influence of different stakeholder groups, then discuss marketing practices and introduce a theoretical framework, in which we propose a supporting role of marketing in the successful design and implementation of CSR. We subsequently test this framework with a survey of U.S. organizations.

\section{Corporate social responsibility and the influence of different stakeholder groups}

Multiple conceptualizations of CSR exist, and a single definition has yet to be agreed on (Andriof and McIntosh, 2001; Garriga and Melé, 2004). Common to the various concepts, however, is the idea that organizations should be not only concerned about making a profit but also engaged in "actions that appear to further some social good, 
beyond the interests of the firm and that which is required by law" (McWilliams et al., 2006: 1).

In turn, CSR has developed from relatively uncoordinated and voluntary practices to more explicit commitments in response to stakeholder pressures and ongoing commitments (Winn et al., 2008). Today, CSR generally refers to business decision making related to ethical values, compliance with legal requirements, and respect for people, communities, and the environment (Carroll, 1979; Maignan et al., 1999). The concept of stakeholders is thus central to CSR, as reflected in, for example, the replacement of "society" with "stakeholder expectations" and the definition of CSR as "the extent to which businesses assume the economic, legal, ethical and discretionary responsibilities imposed on them by their various stakeholders" (Maignan et al., 1999: 457).

Stakeholders may be defined as "groups and individuals who can affect, or are affected by, the achievement of an organization's mission" (Freeman, 1984: 54) or, alternatively, as "those groups who have a stake in or a claim on the firm" (Evan and Freeman, 1988: 97). Stakeholders therefore include the "persons or groups that have, or claim, ownership, rights, or interests in a corporation and its activities, past, present, or future" (Clarkson, 1995: 106). Furthermore, the stakeholder concept may extend to a wider perspective and include all those entities that maintain a "critical eye" on corporate actors (Bomann-Larsen and Wiggen, 2004). Stakeholders thus form the link between the aims and ambitions of the organization and the expectations of society (Whetten et al., 2002). 
Primary stakeholders are those whose direct relationships are essential for the organization to realize its mission; secondary stakeholders are those who support this mission by providing their approval of the organization's activities and thereby making its activities acceptable and giving the organization credibility (Post et al., 1996). Various stakeholders identified in CSR literature (Drumwright, 1994; Greening and Gray, 1994; Lindgreen and Swaen, 2004; Martin, 2002, McIntosh et al., 1998; Pinkston and Carroll, 1994) include managers, employees, suppliers, consumers, and investors as primary stakeholders, as well as governments, nongovernmental organizations, local communities, and trade unions as secondary stakeholders.

For the purposes of our study, and based on the preceding discussion, we choose to define CSR as a stakeholder-oriented concept that extends beyond the organization's boundaries and is driven by an ethical understanding of the organization's responsibility for the impact of its business activities, which prompts it to seek in return society's acceptance of its legitimacy (Gray et al., 1996). That is, good corporate citizens must address the concerns of stakeholders who, whether directly or indirectly, can affect or be affected by the organization's activities (Donaldson and Preston, 1995; Jones, 1995; Waddock, 2001).

\section{Marketing practices}

The idea of mixing the $4 \mathrm{Ps}$ - that is, product, price, place, and promotion - came to dominate marketing early on (Borden, 1965; Culliton, 1948; McCarthy, 1960), known as the 4Ps framework or transaction marketing (Harwood et al., 2008). Changes since then have significantly affected marketing (Lindgreen, 2008). For example, the decline of manufacturing industries saw the concomitant rise in service industries, 
leading to increasing emphasis on the development of services and the way they can be incorporated into goods (Grönroos, 2000), such that marketing and quality align as a coherent value-creation chain (Christopher et al., 2002).

Transaction marketing focuses on attracting new customers from a broad market or specific segment, whose unfulfilled demand might be satisfied through the use of marketing techniques, portfolio analysis, and production (Barton, 1946; Howard and Sheth, 1969; Womer, 1944). Relationship marketing, in contrast, emphasizes the value of maintaining loyal customers to grow profits and sales (Best, 2004; Reichheld, 1996; Storbacka, 2000). As its objective, relationship marketing involves "attracting, maintaining and [...] enhancing customer relationships" (Berry, 1983: 25). To achieve such an objective, marketing must be implemented through relationships, networks, and interactions (Ford, 1998; Gummesson, 1999).

The Contemporary Marketing Practice group suggests a rigorously developed framework for understanding marketing practices (Coviello et al., 2002); as one of its key elements, it does not place distinct boundaries between different marketing practices; different marketing practices are not necessarily independent or mutually exclusive. Tables 1 and 2 summarize the framework; five exchange dimensions and four managerial dimensions characterize transaction marketing and four types of relationship marketing.

\{Insert tables 1 and 2 about here 
Organizations also use database tools to target and maintain customers, dialogue, or develop relationships with their individual customers (i.e., database marketing); employ the Internet and other interactive technologies to create and mediate dialogue with customers (i.e., e-marketing); develop personal interactions between their employees and individual customers (i.e., interaction marketing); and position themselves within a wider marketing network (i.e., network marketing).

\section{Theoretical framework}

Any organization must deal with complexity, dynamism, changing market requirements, and competitive rivalry (Beverland and Lindgreen, 2004; Hunt, 2000; Kotler, 1999). Many of today's organizations offer goods that are not much different from those of their competitors, but they give away a lot of costly service features and add-ons to get the sale. Competitors readily match pricing, and advertising is growing more expensive and less effective. Finally, organizations are spending more on sales promotion, and sales force costs are increasing as well. A sole reliance on transaction marketing may therefore end up costing a lot of money for little gain; relationship marketing, in contrast, is often hailed as an effective means to achieve a sustained competitive market advantage (Sheth, 2001) and create a unique selling proposition (Cravens, 1998).

In addition, many organizations are realizing that because of rising customer expectations, changing employee demands, government legislation and pressure, investor interest in social criteria, and the introduction of new business procurement practices, marketing actually extends beyond the organization and its customers 
(Kotler and Keller, 2006). Organizations therefore perform to satisfy both their customers and other stakeholders by practicing CSR.

Relationship marketing pertains to those relationships with customers and other stakeholders (Gummesson, 1999; Morgan and Hunt, 1994), in which context social responsibility implies that organizations must consider the role that marketing plays in terms of achieving CSR (Kotler and Armstrong, 1999). Only few studies, surprisingly, examine the role of marketing in the design and implementation of CSR (Knox and Gruar, 2007; Lindgreen and Swaen, 2004; Murphy et al., 2005). For example, for an organization that balances its stakeholder management activities, higher stakeholder perceptions indicate a more effective relationship marketing strategy across the organization's stakeholders (Murphy et al., 2005). Another study adapts the Contemporary Marketing Practice framework to accommodate a broader constituency of primary and secondary stakeholders (Knox and Gruar, 2007).

We expect relationships between various types of marketing and various types of CSR. Furthermore, we are interested in measuring the perceived impact of CSR practices on organizational performance. Because our study is centered on theory generation, we propose simply a parsimonious conceptual model at this stage (Figure 1); however, such an exploration of relationships between marketing and CSR has not previously been conducted, so the resulting insights into such relationships should help us develop the CSR concept further.

\{Insert figure 1 about here $\}$ 


\section{METHODOLOGY}

\section{Survey instrument}

The questionnaire asks respondents to provide details about their organization, including characterizations of the organization's business activities, for which respondents can choose from multiple categories; respondents also answer questions about when the organization was established, the proportion of sales revenue generated by sales to export markets, the number of employees, and organizational structure (cf. Lindgreen et al., 2008).

In the questionnaire's second part, we ask respondents to report on their organization's marketing practices with primary and secondary customers. For primary customers, we use 36 indicators based on the nine exchange and managerial aspects of marketing practices, as well as 4 global indicators based on the general descriptions of each practice (cf. Tables 1 and 2; Coviello et al., 2002). For each of these 40 indicators, respondents indicate the extent (five-point Likert scales, $1=$ "strongly disagree" to $5=$ "strongly agree") to which it reflects current practice in their organization. For secondary customers, we only ask respondents about their organizations' general approach to dealing with the customers using the 4 global indicators. Thus, we maintain a manageable questionnaire length.

The third part of the survey relates to the organizations' CSR practices (cf. Beltz et al., 1997; Lindgreen et al., 2008; Maignan et al., 1999). Using five- or seven-point Likert scales ( 1 = "strongly disagree"; 5 or 7 = "strongly agree"), respondents indicate the extent to which their organization has adopted specific corporate practices and how it deals with social, environmental, and ethical issues. Another question 
investigates whether the organization has a specific department devoted to CSR issues or employees who regularly allocate time to such issues.

Finally, because we hope to identify the impact of CSR on performance outcomes, in the fourth part of the survey, we ask for details about sales revenue and return on investment, as well as an evaluation of the organization's performance relative to its main competitor(s) on these two measures ( $1=$ "much worse"; $5=$ "much better"). Respondents also evaluate their organization's performance relative to expectations with regard to improving relations with different stakeholders, improving the social and economic health of the society, attaining desired profitability, improving corporate reputation, and gaining national and international visibility on five-point Likert scales ( 1 = "no effect at all"; 5 = "very high effect"). This part of the survey also builds on existing scales (cf. Lindgreen et al., 2008).

To assess the face validity of the scale items, we submitted the survey and a letter introducing our research objectives to a pretest with eight experienced marketing academics and professionals. These respondents provided feedback and qualitative comments about marketing practices and CSR practices.

\section{Data collection}

\section{Sampling procedure}

We collected data through a nationwide survey of managers of U.S. organizations. Our sample covers a broad range of organizations, including various types of business activities, amounts of sales revenues, numbers of employees, and sales revenues generated by sales to export markets. The survey targets respondents with certain 
functional roles, who are better able to answer the questions as a result of their experience, knowledge of management policies, and access to operational and quality performance data. We identify the following functions as particularly appropriate for our study: executives/owners, marketing/advertising personnel, general management, communication/public relations, market research, customer service, sales/business development, and administration.

All respondents were contacted via e-mail with an invitation to participate in the survey, to which they could respond online, which enables us to capture the completion time and date the questionnaire was returned. Respondents from 523 different U.S. organizations completed the survey and answered all the survey's questions. However, because preliminary tests showed that respondents would need at least 10 minutes to answer the survey, we exclude questionnaires from respondents who spent less than 10 minutes filling out the survey. We therefore retain 441 organizations in our study.

\section{Respondent demographics}

The age of the respondents averages 44 years, as indicated in Table 3 . The majority of respondents hold upper $(63.7 \%)$ or middle $(28.5 \%)$ management positions, and $67 \%$ indicate that their job is marketing or CSR related. On average, the respondents have spent 7.5 years in their current position.

\{Insert table 3 about here $\}$ 
As we indicate in Table 4, the sample represents a variety of organizations $(45.8 \%$ business-to-business and $43.6 \%$ business-to-consumer); the organizations distribute physical goods (36.8\%), services $(57.6 \%)$, and physical goods combined with services (5.7\%). Most (67.5\%) of the organizations employ fewer than 20 employees in marketing positions. Furthermore, $70.9 \%$ of the organizations generate $10 \%$ or less of their sales revenue through sales to export markets. The 2004 sales revenues of $53 \%$ of the organizations were $\$ 10$ million or less, and $17.9 \%$ enjoyed more than $\$ 1,000$ million in sales revenue. For additional information, we refer to Table 4.

Finally, $15.4 \%$ of the organizations have a separate department that regularly allocates time to social, environmental, and ethical issues; $30.7 \%$ have employees who regularly allocate time to these issues; and $53.9 \%$ have neither a separate department nor employees who regularly allocate time to these issues.

\{Insert table 4 about here $\}$

\section{Nonresponse bias}

With regard to nonresponse bias, we check the demographics of the organizations against the general business profile in the United States and find that the sample organizations are typical of the types of businesses prevalent there. Also, we compare early (first 25\%) and late (last 25\%) responses to questions relating to CSR practices and find no significant differences. Therefore, nonresponse bias does not appear to be a problem for our study (Armstrong and Overton, 1977).

\section{Data analysis}


Through exploratory factor analysis in SPSS, we identify the types of marketing practices and CSR practices performed by the organizations; we then include these exploratory factors in the partial least square (PLS) measurement model. We use PLSGraph Version 3.0 (Chin, 2001) to obtain PLS estimates for both the measurement and structural parameters in our structural model. As opposed to the covariance-based or factor-based approach to structural equation modelling implemented, for example, in LISREL, PLS does not require multivariate normal data, places minimum requirements on measurement levels, and is more suitable for small samples (Chin, 1998). Because PLS uses an iterative estimation algorithm, which consists of a series of simple or multiple ordinary least squares regression analyses (Chin, 1998), the path coefficients in structural models can be interpreted as standardized regression coefficients, and the loadings of the measures on their respective constructs indicate factor loadings. Moreover, PLS is more appropriate for models containing complex relationships (i.e., a large number of indicators, constructs, and relationships).

We can obtain an approximation of the required sample size using a path-weighting scheme in which we find the dependent latent variable with the largest number of independent latent variables (Chin and Newsted, 1999). Using a regression heuristic of 10 times this number, we can approximate the required sample size. In our case, we find four independent latent variables, so the required sample size is approximately 40. To ensure our sample size is adequate for the analysis, we conduct a power test, as proposed by Cohen (1998) for the F-test using $\mathrm{R}^{2}$ for the endogenous constructs. Assuming a medium effect size $\left(f^{2}=0.15 ; \mathrm{R}^{2}=0.13\right)$ for the four predictors, a significance level of $\alpha=0.05$, and a desired power of $(1-\beta)=0.80$, our analysis would require a sample size of 84 . Green's (1991) approach yields a required sample size of 
81. Both figures show that with our sample size of 441 , we have more than sufficient power to estimate our model in PLS.

We adopt the procedure advocated by Chin (1998) and Hulland (1999) to evaluate our PLS model with a two-stage procedure. In the first stage, we assess the psychometric properties of the measurement instruments in a null (measurement) model without specifying structural relationships. In the second stage, we test the structural model that represents the relationships among constructs. This approach ensures that the measures are valid and reliable before we draw conclusions about the hypothesized links among the constructs themselves.

\section{RESULTS AND DISCUSSION}

\section{Exploratory factor analysis}

\section{Marketing practices}

Using factorial analysis with Varimax rotation, we identify four reliable types of marketing practices: transactional marketing (5 items; explained variance $=10.0 \% ; \alpha$ $=0.787$ ), database and e-marketing (12 items; explained variance $=23.2 \% ; \alpha=$ 0.939), interaction marketing (6 items; explained variance $=13.5 \% ; \alpha=0.871$ ), and network marketing ( 8 items; explained variance $=14.9 \% ; \alpha=0.908$ ). We delete 19 items for which the loadings do not exceed 0.5.

Our analysis groups database marketing and e-marketing together. The former practice uses database technology to acquire customer information and identify those customers to be retained, and the latter exploits the Internet and other interactive technologies to create two-way dialogue between organizations and identified 
customers. These two marketing practices in many respects thus are very similar, which may explain why our analysis does not distinguish between them. Furthermore, we reemphasize the difficulty of setting clear boundaries between the different types of marketing practices (Coviello et al., 2002).

\section{Corporate social responsibility practices}

Using factorial analysis with Varimax rotation, we identify five reliable dimensions of CSR practices that relate to customers and suppliers ( 3 items; explained variance $=$ $14.3 \% ; \alpha=0.912$ ), employees ( 6 items; explained variance $=17.8 \% ; \alpha=0.924$ ), financial investors (6 items; explained variance $=10.7 \% ; \alpha=0.941)$, philanthropy $(6$ items; explained variance $=16.1 \% ; \alpha=0.938$ ), and the environment (6 items; explained variance $=18.4 \% ; \alpha=0.941)$. On a seven-point scale, respondents indicated that their organizations have adopted specific CSR practices relating to employees $($ mean $=5.25 ; \mathrm{SD}=1.43)$, customers and suppliers $($ mean $=5.22 ; \mathrm{SD}=$ 1.29 ), and financial investors (mean $=5.16 ; \mathrm{SD}=1.67$ ). To a lesser extent, the organizations also apply CSR practices related to philanthropy $($ mean $=4.71 ; \mathrm{SD}=$ $1.57)$ and the environment $($ mean $=4.62 ; \mathrm{SD}=1.54)$.

Next, we examine the measurement model in PLS to generate information about the reliability, convergent validity, and discriminant validity of the measurement model (Chin, 1998; Fornell and Bookstein, 1982). As far as the psychometric properties of the measures are concerned, we specify a null model in which we include all constructs, without specifying structural paths in PLS-Graph Version 3.0 (Chin, 2001), which is analogous to confirmatory factor analysis in covariance-based structural equation models. To assess reliability, we use composite reliability and 
average variance extracted (AVE) (Chin, 1998; Fornell and Larcker, 1981). The composite scale reliability ranges between 0.856 and 0.962 , exceeding the cut-off value of 0.7 suggested by Nunnally and Bernstein (1994). The AVEs range between 0.542 and 0.895 and thus exceed the 0.5 cut-off value proposed by Fornell and Larcker (1981). Convergent validity can be evaluated by inspecting the factor loadings of the measures on their respective constructs (Chin, 1998). As we show in Table 5, the PLS analysis confirms the earlier factor analyses for most concepts, and all items (except two performance items) load more than 0.7 on their respective latent variables (Hulland, 1999).

\{Insert table 5 about here $\}$

We can assess discriminant validity by examining whether each construct shares more variance with its measures than it shares with other constructs in the model (Chin, 1998; Hulland, 1999). Therefore, the square root of the AVE should exceed the construct intercorrelations in the model; an inspection of Table 6 reveals that construct intercorrelations in the model do not exceed the square root of the AVE for the constructs. Taken together, these tests indicate that the psychometric properties of the instruments are adequate to enable interpretation of the structural model.

\{Insert table 6 about here $\}$

\section{Structural model}

To test the effects and statistical significance of the parameters in the structural model, we use a bootstrapping procedure with 250 resamples with individual sign 
reprocessing (Chin, 1998, 2001). Figure 2 presents the results from PLS related to the structural model.

\section{\{Insert figure 2 about here $\}$}

We note several key points. In particular, the exploratory results confirm the proposition that CSR practices are more prevalent in organizations that employ relational marketing practices. All types of CSR practices receive positive influences by one or more types of relational marketing practices. In the process of building and engaging in relationships, networks, and interactions with customers and other stakeholders, managers look for CSR practices that can generate trust, loyalty, and support from stakeholders, especially as product differentiation becomes increasingly difficult (Berens et al., 2002; Brown and Dacin, 1997; Kennedy et al., 2001; Swaen, 2004). To demonstrate that it is aware of the environmental, social, and ethical issues that its stakeholders face, an organization could engage in a dialogue with the stakeholders to learn what these issues are; the dialogue then becomes a means to support the successful establishment, maintenance, and enhancement of the interaction process (Schultz et al., 1992). For example, an organization could set up a Web site to communicate about the organization's involvement in CSR (Esrock and Leichty, 1998). Developing CSR practices involves learning over time and the ability to understand the specific context and confluence of stakeholder expectations, especially because they can change over time. This learning and ability in turn require communication and dialogue with stakeholders; relational marketing practices support such communication. 
Specifically, we observe the central role played by interaction marketing and network marketing in developing CSR practices related to different stakeholders. Organizations appear to realize that they operate in networks and that they must manage their relationships, networks, and interactions to ensure they fit the concerned stakeholders.

Furthermore, database marketing and e-marketing play roles in developing CSR practices related to investors and the environment. In its use of database technology, database marketing primarily attempts to acquire customer information. For example, it can collect information about investors and nongovernmental organizations active in the environmental field and determine their expectations on various issues. Emarketing goes one step further by creating and mediating two-way dialogue between the organization and identified stakeholders; the purpose is to create informationgenerating dialogue with these stakeholders. With e-marketing, most organizations form discussion forums to stimulate stakeholder dialogues (Esrock and Leichty, 1998). Consider, for example, an organization that is responding to customers' increased worry for the environment. It must collect information about customers' concerns and, internally, consult with different departments of the company, including operations management (e.g., how to produce the goods in a more environmentallyfriendly manner), packaging (e.g., how to package the goods using fewer materials), or the marketing department (e.g., how to communicate that the goods are being produced in a more environmentally-friendly manner). To implement CSR properly, it is necessary to fertilize a cross-departmental culture within the organization (Drumwright, 1994, 1996). In other words, social and environmental challenges 
require collaboration across an organization's different departments; such collaboration is dominant in relationship marketing.

Adopting a relational marketing perspective would appear to prompt organizations to attribute more importance to social, ethical, and environmental considerations. According to Gundlach and Murphy (1993), in the move from a transactional perspective to a relational perspective, references to the law and contracts are less important, whereas ethical issues become essential.

However, transaction marketing still supports CSR practices related to customers, suppliers, and investors. The stakeholders in this frame are the economic partners of the organization; they could be considered transactional, formal stakeholders for whom transactional marketing still has some logic. For instance, CSR activities might be diffused to a large audience through mass communication, a tool of transactional marketing. Another potential explanation could imply that some organizations have just initiated CSR activities and have not yet developed the marketing practices that are most suitable for CSR.

A combination of transactional and relational marketing practices seems a key element in developing CSR, given the broadness of CSR, the type of CSR activities, and the type of stakeholders. This finding is in line with work conducted by the Contemporary Marketing Practice group (e.g., Coviello et al., 2001, 2002) and discussed by Brookes and Palmer (2004). Their work analyzes an aggregate sample of respondents using clustering techniques; the findings indicate that practices are not necessarily exclusively practiced but instead can be practiced concurrently. 
Finally, we contend that by reaching out to its stakeholders, an organization can increase its revenues and profits, thereby improving its chance of surviving in the long run. Through a value process, the organization learns how stakeholders perceive and value the economic, social, and environmental aspects of CSR. Our findings illustrate the impact of CSR activities related to philanthropy and the environment on the organization's performance. This result therefore confirms previous research noting a positive link between investment in CSR and organizational performance.

\section{CONCLUSIONS}

Our study offers insights into how marketing supports the design and implementation of CSR; the specific type(s) of marketing practice(s) depend on the type of issues and the type of stakeholders. Our findings further demonstrate how CSR must reach out to many different stakeholders; the organization listens and responds to stakeholders that form part of the organization's relationships, networks, and interactions. The organization should avoid making assumptions. In this sense, it is becoming dangerous - even for experienced managers - to make assumptions about what is best for stakeholders. For example, in the genetically modified organism debate, Monsanto recognized that it erred when it failed to take into account the perceptions of the different publics in Europe. Companies must attempt to understand the realities of the business through the eyes of stakeholders, which requires an ability to comprehend how stakeholders perceive the business and an openness to improvement and change.

As is the case for most research, our study has several limitations that affect our interpretations and that therefore should be considered. First, our sample frame 
development might favor the inclusion of respondents who are interested in a financial reward for filling out a survey but not necessarily in providing correct answers. Additional research should investigate this respondent qualification issue.

Second, we rely on single respondents from the organization and do not include any informants from the organizations' stakeholder groups. Although much research takes the perspective of a single organization rather than the relationship between an organization and its stakeholders, we recognize that stakeholders might characterize an organization's CSR practices differently than the organization does. To exclude this potential bias, further research should employ a multi-informant research design. Surveys of consumers, employees, investors, and public organizations could be combined to obtain a better assessment of CSR practices and a deeper understanding of the role of different stakeholders in the development of CSR practices and their benefits.

Third, our analysis reports on managerial evaluations, not actual corporate behaviors. The gathered data reflect how managers evaluate CSR practices, stakeholders' influences, and performance outcomes but cannot assess the extent to which these perceptions link to actual CSR practices and performance outcomes. We assume that the respondents surveyed are sufficiently knowledgeable and willing to provide an accurate depiction of their organization, but additional research should include objective indicators of CSR practices, such as the amount of philanthropic donations or an analysis of layoff practices. 
Fourth, also with regard to respondents' evaluations of CSR policies and practices, because most respondents claim their organization performs better than its competitors, we posit that respondents may have decided to participate in the survey because their organization actually is involved in CSR. Therefore, our study suffers a potential self-selection bias. Alternatively, managers may want to present their organization in a better light than is accurate, which would reflect on our methodology, because our survey is based solely on statements from managers of these organizations.

Fifth, this study involves only U.S. organizations, which means it may be used as a benchmark for analyzing CSR policies and practices in different countries. Additional research should examine cross-cultural differences in CSR practices, antecedents, and benefits. Such research would help international managers determine whether they should adapt their CSR policies to different cultures or if global practices are feasible.

These limitations should be considered when interpreting our results, but despite them, we believe our study offers several important contributions. First, through a quantitative investigation, we extend understanding of organizations' current CSR policies and practices. Second, our results indicate that managers do not believe that meeting social demands come at the expense of achieving set performance outcomes. Instead, investing in CSR enables organizations to address the expectations of their stakeholders. Ultimately, our results thus highlight the marketing value of an active CSR policy. 


\section{REFERENCES}

Andriof, J. and McIntosh, M. (2001) Perspectives on Corporate Citizenship. Greenleaf Publishing, UK.

Armstrong, J.S. and Overton, T.S. (1977) 'Estimating non-response bias in mail services', Journal of Marketing Research, 14(3), 396-402.

Aupperle, K.E., Carroll, A.B., and Hatfield, J.D. (1985) 'An empirical examination of the relationship between corporate social responsibility and profitability', Academy of Management Journal, 28(2), 446-463.

Barton, S.G. (1946) 'The movement of branded goods to the consumer', in Blankenship, A.D. (Ed.), How to Conduct Consumer and Opinion Research, Harper \& Bros., New York, pp. 58-70.

Beltz, F., Kestemont, M.-P., and Strannegard, L. (1997) International Business Environmental Barometer, Cappelen Akademisk Forlag, Copenhagen.

Berens, G., van Riel, C.B.M., and van Bruggen, G.H. (2002) 'The added value of corporate brands', ERIM Report Series, No. ERS-2002-43-ORG. Available at SSRN: http://ssrn.com/abstract=370986.

Berry, L.L. (1983) 'Relationship marketing', in Berry, L.L., Shostack, G.L., and Upah, G.D. (Eds.), Emerging Perspectives on Services Marketing, American Marketing Association, Chicago-Illinois, 25-28.

Bertels, S. and Peloza, J. (2008) 'Running just to stand still? Managing CSR reputation in an era of ratcheting expectations', Corporate Reputation Review, 11(1), 56-72.

Best, R.J. (2004) Market-Based Management, 3rd ed., Pearson Education, Upper Saddle River, NJ. 
Beverland, M.B. and Lindgreen, A. (2004) 'Relationship use and market dynamism: a model of relationship evolution', Journal of Marketing Management, 20(7-8), 825858.

Bhattacharya, C.B. and Sen, S. (2004) 'Doing better at doing good: When, why, and how consumers respond to corporate social initiatives', California Management Review, 47(1), 9-24.

Bomann-Larsen, L. and Wiggen, O. (2004) Responsibility in World Business: Managing Harmful Side-effects of Corporate Activity, United Nations University Press, Tokyo.

Borden, N.H. (1965) "The concept of the marketing mix", in Schwartz, G. (Ed.), Science in Marketing, John Wiley \& Sons, New York, 386-397.

Brookes, R. and Palmer, R. (2004) The New Global Marketing Reality, Palgrave, London.

Brown, T.J. and Dacin, P.A. (1997) 'The company and the product: Corporate associations and consumer product responses', Journal of Marketing, 61(1), 68-84.

Carroll, A. B. (1979) 'A three-dimensional conceptual model of corporate performance', Academy of Management Review, 4 (4), 497-505.

Chin, W. (1998) 'The partial least squares approach to structural equation modeling', in Marcoulides, G.A. (Ed.), Modern Business Research Methods, Lawrence Erlbaum Associates, Mahwah, NJ, 295-336.

Chin, W. (2001) PLS-Graph User's Guide Version 3.0, C.T. Bauer College of Business, University of Houston, Houston, TX.

Chin, W.W. and Newsted, P.R. (1999) 'Structural equation modeling analysis with small samples using partial least squares', In Hoyle, R.H. (Ed.), Statistical 
Strategies for Small Sample Research, Sage Publications, Thousand Oaks, CA, 307-341.

Christopher, M., Payne, A., and Ballantyne, D. (2002) Relationship Marketing, Butterworth Heinemann, Oxford.

Clarkson, M.B.E. (1995) 'A stakeholder framework for analyzing and evaluating corporate social performance', Academy of Management Review, 20(1), 92-117.

Cohen, J. (1988) Statistical Power Analysis for the Behavioral Sciences. Lawrence Erlbaum Associates, Hillsdale, NJ.

Coviello, N.E., Brodie, R.J., Danaher, P.J., and Johnston, W.J. (2002) 'How firms relate to their markets: an empirical examination of contemporary marketing practices', Journal of Marketing, 66(3), 33-46.

Coviello, N., Milley, R., and Marcolin, B. (2001) 'Understanding IT-enabled interactivity in contemporary marketing', Journal of Interactive Marketing, 15(4), $18-33$

Cravens, D.W. (1998) 'Implementation strategies in the market-driven era', Journal of Academy of Marketing Science, 26(3), 237-241.

Culliton, J.W. (1948) The Management of Marketing Costs, Harvard University, Boston, MA.

Donaldson, T. and Preston, L.E. (1995) 'The stakeholder theory of the corporation: concepts, evidence, and implications', Academy of Management Review, 20(1), 6591.

Drumwright, M.E. (1994) 'Socially responsible organizational buying: environmental concern as a noneconomic buying criterion', Journal of Marketing, 58(3), 1-19.

Drumwright, M.E. (1996) 'Company advertising with a social dimension: the role of noneconomic criteria', Journal of Marketing, 60(4), 71-87. 
Dunphy, D., Griffiths, A. and Benn, S. (2003) Organizational Change for Corporate Sustainability, Routledge, London.

Esrock, S.L. and Leichty, G.B. (1998) 'Social responsibility and corporate web pages: Self-presentation or agenda-setting? ' Public Relations Review, 24 (3), 305-319.

Evan, W.M. and Freeman, R.E. (1988) 'A stakeholder theory of the modern corporation: Kantian capitalism', in Beauchamp, T.L. and Bowie, N.E. (Eds.), Ethical Theory and Business. Englewood Cliffs, NJ: Prentice Hall, 97-106.

Ford, D. (1998) Managing Business Relationships, John Wiley \& Sons, Chichester.

Fornell, C. and Bookstein, F. (1982) 'Two structural equation models: LISREL and PLS applied to consumer exit-voice theory', Journal of Marketing Research, 19(4), $440-452$

Fornell, C. and Larcker, D. (1981) 'Evaluating structural equation models with unobservable variables and measurement error', Journal of Marketing Research, 18(1), 39-50.

Freeman, R.E. (1984) Strategic Management: A Stakeholder Approach, Pitman Publishing, Boston, MA.

Garriga, E. and Melé, D. (2004) 'Corporate social responsibility theories: Mapping the territory', Journal of Business Ethics, 53(1/2), 51-71.

Gray, R., Owen, D., and Adams, C. (1996) Accounting and Accountability: Changes and Challenges in Corporate Social and Environmental Reporting, Prentice-Hall, London.

Green, S.B. (1991) 'How many subjects does it take to do a regression analysis?' Multivariate Behavioral Research, 26(3), 499-510.

Greenfield, W.M. (2004) 'In the name of corporate social responsibility', Business Horizons, 47(1), 19-28. 
Greening, D.W. and Gray, B. (1994) 'Testing a model of organizational response to social and political issues', Academy of Management Journal, 37(3), 467-498.

Griffin, J.J. and Mahon, J.F.(1997) 'The corporate social performance and corporate financial performance debate', Business and Society, 36(1), 5-31.

Grönroos, C. (2000) Service Management and Marketing, 2nd ed., John Wiley \& Sons, Chichester.

Gummesson, E. (1999) Total Relationship Marketing, Butterworth-Heinemann, Oxford.

Gundlach G.T. and Murphy, P.E. (1993), 'Ethical and legal foundations of relational marketing exchanges', Journal of Marketing, 57 (3), 35-46.

Harwood, T., Garry, T., and Broderick, A. (2008) Relationship Marketing: Perspectives, dimensions and contexts, McGraw-Hill, London.

Howard, J.A. and Sheth, J.N. (1969) The Theory of Buyer Behavior, John Wiley \& Sons, New York.

Hulland, J. (1999) 'Use of partial least squares (PLS) in strategic management research: a review of four recent studies', Strategic Management Journal, 20(2), 195-204

Hunt, S.D. (2000) A General Theory of Competition, Sage Publications, Thousand Oaks, CA.

Jones, T.M. (1995) 'Instrumental stakeholder theory: a synthesis of ethics and economic', Academy of Management Review, 20(2), 404-437.

Kennedy, M.S., Ferrell, L.K., and LeClair, D.T. (2001) 'Consumers' trust of salesperson and manufacturer: An empirical study', Journal of Business Research, 51(1), 73-86 
Knox, S. and Gruar, C. (2007) 'The application of stakeholder theory to relationship marketing strategy development in a non-profit organization', Journal of Business Ethics, 75(2), 115-135.

Kotler, P. (1999) Kotler on Marketing, The Free Press, New York.

Kotler, P. and Armstrong, G. (1999) Principles of Marketing, 8th ed., Prentice-Hall, Upper Saddle River, NJ.

Kotler, P. and Keller, K.L. (2006) Marketing Management, 12th ed., Prentice Hall, Upper Saddle River, NJ.

Kotler, P. and Lee, N. (2005) Corporate Social Responsibility: Doing the Most Good for Your Company and Your Cause, John Wiley \& Sons, Hoboken, NJ.

Lichtenstein, D.R., Drumwright, M.E., and Braig, B.M. (2004) 'The effect of corporate social responsibility on customer donations to corporate-supported nonprofits', Journal of Marketing, 68(4), 16-32.

Lindgreen, A. (2008) Managing Market Relationships: Methodological and Empirical Insights, Gower Publishing, Aldershot, forthcoming.

Lindgreen, A. and Swaen, V. (2004) 'Corporate citizenship: Let mot relationship marketing escape the management toolbox', Corporate Reputation Review 7(4), 346-363.

Lindgreen, A., Swaen, V., and Johnston, W.J. (2008) 'Corporate social responsibility: an empirical investigation of U.S. organizations', Journal of Business Ethics, in press.

Maignan, I. and Ferrell, O.C. (2001) 'Antecedents and benefits of corporate citizenship: an investigation of French businesses', Journal of Business Research, 51(1), 37-51. 
Maignan, I., Ferrell, O.C., and Hult, T. (1999) 'Corporate citizenship: cultural antecedents and business benefits', Journal of the Academy of Marketing Science, 27(4), 455-469.

Maignan, I. and Ralston, D.A. (2002) 'Corporate social responsibility in Europe and the U.S.: Insights from businesses' self-presentations', Journal of International Business Studies, 33(3), 497-514.

Martin, R.L. (2002) 'The virtue matrix: calculating the return on corporate responsibility', Harvard Business Review, 80(3), 68-75.

Matten, D., Crane, A., and Chapple, W. (2003) 'Behind the mask: Revealing the true face of corporate citizenship', Journal of Business Ethics, 45(1/2), 109-120.

McCarthy, E. J. (1960), Principles of Marketing, Irwin, Boston, MA.

McIntosh, M., Leipziger, D., Jones, K., and Coleman, G. (1998) Corporate Citizenship: Successful Strategies for Responsible Companies, Financial Times/Pitman Publishing, UK.

McWilliams, A., Siegel, D.S., and Wright, P.M. (2006) 'Corporate social responsibility: Strategic implications', Journal of Management Studies, 43(1), 118.

McWilliams, A., Van Fleet, D.D., and Cory, K. (2002) 'Raising rivals' costs through political strategy: An extension of the resource-based theory', Journal of Management Studies, 39(5), 707-723.

Morgan, R.M. and Hunt, S.D. (1994) 'The commitment-trust theory of relationship marketing', Journal of Marketing, 58(3), 20-38.

Murphy, B., Maguiness, P., Pescott, C., Wislang, S., Jinwu, M., and Wang, R. (2005) 'Stakeholder perceptions presage holistic stakeholder relationship marketing performance', European Journal of Marketing, 39(9/10), 1025-1048. 
Nunnally, J.C. and Bernstein, I.H. (1994) Psychometric Theory, McGraw-Hill Series in Psychology, McGraw-Hill, New York.

Pearce, J.A. and Doh, J.P. (2005) 'High-impact collaborative social initiatives', MIT Sloan Management Review, 46(3), 30-39.

Pinkston, T.S. and Carroll, A.B. (1994) 'Corporate citizenship perspectives and foreign direct investment in the US', Journal of Business Ethics, 13(2), 157-169.

Post, J.E., Frederick, W.C., Lawrence, A.T., and Weber, J. (1996) Business and Society. Corporate Strategy, Public Policy and Ethics, McGraw-Hill, New York.

Reichheld, F. F. (1996) The Loyalty Effect, Harvard Business School Press, Boston, MA.

Sheth, J. N. (2001) 'From international to integrated marketing', Journal of Business Research, 51(1), 5-9.

Smith, C. (2003), 'Corporate social responsibility: whether or how?' California Management Review, 45 (4), 52-76.

Snider, J., Hill, R.P., and Martin, D. (2003) 'Corporate social responsibility in the 21st century: A view from the world's most successful firms', Journal of Business Ethics, 48(2), 175-187.

Schultz, D.E., Tannenbaum, S.I., and Lauterborn, R.F. (1992) Integrated Marketing Communications, NTC Publishing, Lincolnwood, IL.

Storbacka, K. (2000) 'Customer profitability: analysis and design issues', in Sheth, J. N. and Parvatiyar, A. (Eds.), Handbook of Relationship Marketing, Sage Publications, Thousand Oaks, CA, 565-586.

Swaen, V. (2004) Etude des perceptions et des réactions des consommateurs face aux activités citoyennes des entreprises: Application à deux catégories de produits, Université catholique de Louvain, Louvain-la-Neuve. 
Waddock, S. (2001) 'Integrity and mindfulness: foundations of corporate citizenship', in Andriof, J. and McIntosh, M. (Eds.), Perspectives on Corporate Citizenship, Greenleaf Publishing, UK, 26-38.

Whetten, D.A., Rands, G., and Godfrey, P. (2002) 'What are the responsibilities of business to society?' in A. Pettigrew, H. Thomas, and R. Whittington (Eds.), Handbook of Strategy and Management, London: Sage Publications, 373-408.

Williams, R.J. and Barett, J.D. (2000) 'Corporate philanthropy, criminal activity, and firm reputation: is there a link?' Journal of Business Ethics, 26(4), 341-350.

Winn, M.I., MacDonald, P., and Zietsma, C. (2008) 'Managing industry reputation: the dynamic tension between collective and competitive reputation management strategies', Corporate Reputation Review, 11(1), 35-55.

Womer, S. (1944) 'Some applications of the continuous consumer panel', Journal of Marketing, 8(4), 132-136. 
Table 1. Types of marketing classified by exchange dimensions

\begin{tabular}{|c|c|c|c|c|c|}
\hline & \multirow{2}{*}{$\begin{array}{c}\begin{array}{c}\text { Transactional } \\
\text { Perspective }\end{array} \\
\text { Type: Transaction marketing }\end{array}$} & \multicolumn{4}{|c|}{$\begin{array}{l}\text { Relational } \\
\text { Perspective }\end{array}$} \\
\hline & & Type: Database marketing & Type: E-marketing & Type: Interaction marketing & Type: Network marketing \\
\hline Purpose of exchange & Economic transaction & $\begin{array}{l}\text { Information and economic } \\
\text { transaction }\end{array}$ & $\begin{array}{l}\text { Information-generating } \\
\text { dialogue between a seller and } \\
\text { many identified buyers }\end{array}$ & $\begin{array}{l}\text { Interpersonal relationships } \\
\text { between a buyer and seller }\end{array}$ & $\begin{array}{l}\text { Connected relationships } \\
\text { between firms }\end{array}$ \\
\hline Nature of communication & Firm 'to' mass market & $\begin{array}{l}\text { Firm 'to' targeted segment or } \\
\text { individuals }\end{array}$ & $\begin{array}{l}\text { Firm using technology to } \\
\text { communicate 'with' and } \\
\text { 'among' many individuals } \\
\text { (who may form groups) }\end{array}$ & $\begin{array}{l}\text { Individuals 'with' individuals } \\
\text { (across organizations) }\end{array}$ & $\begin{array}{l}\text { Firms 'with' firms (involving } \\
\text { individuals) }\end{array}$ \\
\hline Type of contact & Arms-length, impersonal & Personalized (yet distant) & Interactive (via technology) & $\begin{array}{l}\text { Face-to-face, interpersonal } \\
\text { (close, based on commitment, } \\
\text { trust, and co-operation) }\end{array}$ & $\begin{array}{l}\text { Impersonal - interpersonal } \\
\text { (ranging from distant to } \\
\text { close) }\end{array}$ \\
\hline Duration of exchange & $\begin{array}{l}\text { Discrete (yet perhaps over } \\
\text { time) }\end{array}$ & Discrete and over time & $\begin{array}{l}\text { Continuous (but interactivity } \\
\text { occurs in real time) }\end{array}$ & $\begin{array}{l}\text { Continuous (ongoing and } \\
\text { mutually adaptive, may be } \\
\text { short or long term) }\end{array}$ & $\begin{array}{l}\text { Continuous (stable yet } \\
\text { dynamic, may be short or } \\
\text { long term) }\end{array}$ \\
\hline Formality in exchange & Formal & $\begin{array}{l}\text { Formal (yet personalized via } \\
\text { technology) }\end{array}$ & $\begin{array}{l}\text { Formal (yet customized } \\
\text { and/or personalized via } \\
\text { interactive technology) }\end{array}$ & $\begin{array}{l}\text { Formal and informal (i.e., } \\
\text { both a business and social } \\
\text { level) }\end{array}$ & $\begin{array}{l}\text { Formal and informal (i.e., } \\
\text { both a business and social } \\
\text { level) }\end{array}$ \\
\hline
\end{tabular}

Source: Coviello et al. (2001: 28) 
Table 2. Types of marketing classified by managerial dimensions

\begin{tabular}{|c|c|c|c|c|c|}
\hline & \multirow{2}{*}{$\begin{array}{c}\begin{array}{c}\text { Transactional } \\
\text { Perspective }\end{array} \\
\text { Type: Transaction marketing }\end{array}$} & \multicolumn{4}{|c|}{$\begin{array}{l}\text { Relational } \\
\text { Perspective }\end{array}$} \\
\hline & & Type: Database marketing & Type: E-marketing & Type: Interaction marketing & Type: Network marketing \\
\hline Managerial intent & $\begin{array}{l}\text { Customer attraction (to satisfy } \\
\text { the customer at a profit) }\end{array}$ & $\begin{array}{l}\text { Customer retention (to } \\
\text { satisfy the customer, } \\
\text { increase profit, and attain } \\
\text { other objectives, such as } \\
\text { increased loyalty, decreased } \\
\text { customer risk, etc.) }\end{array}$ & $\begin{array}{l}\text { Creation of IT-enabled } \\
\text { dialogue }\end{array}$ & $\begin{array}{l}\text { Interaction (to establish, } \\
\text { develop, and facilitate a co- } \\
\text { operative relationship for } \\
\text { mutual benefit) }\end{array}$ & $\begin{array}{l}\text { Co-ordination (interaction } \\
\text { between sellers, buyers, and } \\
\text { other parties across multiple } \\
\text { firms for mutual benefit, } \\
\text { resource exchange, market } \\
\text { access, etc.) }\end{array}$ \\
\hline Managerial focus & Product or brand & $\begin{array}{l}\text { Product/brand and customers } \\
\text { (in a targeted market) }\end{array}$ & $\begin{array}{l}\text { Managing IT-enabled } \\
\text { relationships between the firm } \\
\text { and many individuals }\end{array}$ & $\begin{array}{l}\text { Relationships between } \\
\text { individuals }\end{array}$ & $\begin{array}{l}\text { Connected relationships } \\
\text { between firms (in a network) }\end{array}$ \\
\hline Managerial investment & $\begin{array}{l}\text { Internal marketing assets } \\
\text { (focusing on product/service, } \\
\text { price, distribution, promotion } \\
\text { capabilities) }\end{array}$ & $\begin{array}{l}\text { Internal marketing assets } \\
\text { (emphasizing } \\
\text { communication, } \\
\text { information, and database } \\
\text { technology capabilities) }\end{array}$ & $\begin{array}{l}\text { Internal operational assets (IT, } \\
\text { website, logistics); functional } \\
\text { systems integration }\end{array}$ & $\begin{array}{l}\text { External market assets } \\
\text { (focusing on establishing and } \\
\text { developing a relationship } \\
\text { with another individual) }\end{array}$ & $\begin{array}{l}\text { External market assets } \\
\text { (focusing on developing the } \\
\text { firms position in a network of } \\
\text { firms) }\end{array}$ \\
\hline Managerial level & $\begin{array}{l}\text { Functional marketers (e.g., } \\
\text { sales manager, product } \\
\text { manager) }\end{array}$ & $\begin{array}{l}\text { Specialist marketers (e.g., } \\
\text { customer service manager, } \\
\text { loyalty manager) }\end{array}$ & $\begin{array}{l}\text { Marketing specialists (with) } \\
\text { technology specialists; senior } \\
\text { managers }\end{array}$ & $\begin{array}{l}\text { Employees and managers } \\
\text { from across functions and } \\
\text { levels in the firm }\end{array}$ & Senior manager \\
\hline
\end{tabular}

Source: Coviello et al. (2001: 28) 
Table 3. Respondent demographics

\begin{tabular}{|c|c|c|}
\hline Demographic Variable & Number & Percentage \\
\hline \multicolumn{3}{|l|}{ Level of job position } \\
\hline Upper management & 277 & 63.7 \\
\hline Middle management & 124 & 28.5 \\
\hline Lower management & 34 & 7.8 \\
\hline Missing & 6 & \\
\hline \multicolumn{3}{|l|}{ Number of months in current job position } \\
\hline Less than 36 months & 118 & 26.8 \\
\hline 36 months, but less than 72 months & 132 & 30.0 \\
\hline 72 months, but less than 120 months & 72 & 16.4 \\
\hline 120 months or more & 118 & 26.8 \\
\hline Missing & 1 & \\
\hline \multicolumn{3}{|l|}{ Marketing/CSR related job position } \\
\hline Job is marketing/CSR related & 295 & 67.0 \\
\hline Job is not marketing/CSR related & 145 & 33.0 \\
\hline Missing & 1 & \\
\hline \multicolumn{3}{|l|}{ Gender } \\
\hline Male & 436 & 99.1 \\
\hline Female & 4 & 0.9 \\
\hline Missing & 1 & \\
\hline \multicolumn{3}{|l|}{ Age } \\
\hline 35 years old or younger & 97 & 22.1 \\
\hline Older than 35 years old, but not more than 45 years old & 129 & 29.5 \\
\hline Older than 45 years old, but not more than 55 years old & 138 & 31.5 \\
\hline More than 55 years old & 74 & 16.9 \\
\hline Missing & 3 & \\
\hline
\end{tabular}


Table 4 . Organization demographics and performance outcomes

Demographic or Performance Outcome Variable

\begin{tabular}{|c|c|c|}
\hline & Number & Percentage \\
\hline $\begin{array}{l}\text { Types of goods and services } \\
\text { Business-to-business } \\
\text { Business-to-consumer } \\
\text { Both business-to-business and business-to-consumer } \\
\text { Missing }\end{array}$ & $\begin{array}{l}169 \\
161 \\
39 \\
72\end{array}$ & $\begin{array}{l}45.8 \\
43.6 \\
10.6\end{array}$ \\
\hline $\begin{array}{l}\text { Types of products } \\
\text { Physical goods } \\
\text { Services } \\
\text { Both physical goods and services } \\
\text { Missing }\end{array}$ & $\begin{array}{l}136 \\
213 \\
21 \\
71\end{array}$ & $\begin{array}{l}36.8 \\
57.6 \\
5.7\end{array}$ \\
\hline $\begin{array}{l}\text { Establishment of organization } \\
\text { Less than } 10 \text { years ago } \\
10 \text { years ago, but less than } 30 \text { years ago } \\
30 \text { years ago or more } \\
\text { Missing }\end{array}$ & $\begin{array}{l}129 \\
144 \\
158 \\
10\end{array}$ & $\begin{array}{l}29.9 \\
33.4 \\
36.7\end{array}$ \\
\hline $\begin{array}{l}\text { Organizational structure } \\
\text { A strategic business unit in a larger corporation } \\
\text { A division in a larger corporation } \\
\text { A plant in a larger corporation } \\
\text { A subsidiary of a larger corporation } \\
\text { Missing }\end{array}$ & $\begin{array}{l}132 \\
85 \\
13 \\
48 \\
163\end{array}$ & $\begin{array}{l}47.5 \\
30.6 \\
4.7 \\
17.3\end{array}$ \\
\hline $\begin{array}{l}\text { Number of employees } \\
\text { Less than } 20 \text { employees } \\
20 \text { employees, but less than } 100 \text { employees } \\
100 \text { employees, but less than } 1,000 \text { employees } \\
1,000 \text { employees or more } \\
\text { Missing }\end{array}$ & $\begin{array}{l}165 \\
65 \\
79 \\
127 \\
5\end{array}$ & $\begin{array}{l}37.8 \\
14.9 \\
18.1 \\
29.1\end{array}$ \\
\hline $\begin{array}{l}\text { Number of employees in marketing } \\
\text { Less than } 20 \text { employees } \\
20 \text { employees or more } \\
\text { Missing }\end{array}$ & $\begin{array}{l}272 \\
131 \\
38\end{array}$ & $\begin{array}{l}67.5 \\
32.5\end{array}$ \\
\hline $\begin{array}{l}\text { Proportion of sales generated by sales to export markets } \\
10 \% \text { or less } \\
\text { More than } 10 \% \\
\text { Missing }\end{array}$ & $\begin{array}{l}266 \\
109 \\
66\end{array}$ & $\begin{array}{l}70.9 \\
29.1\end{array}$ \\
\hline $\begin{array}{l}\text { Sales revenue } \\
\text { US\$ } 10 \text { million or less } \\
\text { More than US\$ } 10 \text { million } \\
\text { Missing }\end{array}$ & $\begin{array}{l}210 \\
186 \\
45\end{array}$ & $\begin{array}{l}53.0 \\
47.0\end{array}$ \\
\hline & Mean & $S D$ \\
\hline $\begin{array}{l}\text { Growth in sales revenue relative to competitors }{ }^{\mathrm{a}} \\
\text { Return on investment relative to competitors } \\
\text { Performance relative to expectation } \mathrm{s}^{\mathrm{a}}\end{array}$ & $\begin{array}{l}3.68 \\
3.62\end{array}$ & $\begin{array}{l}1.14 \\
1.13\end{array}$ \\
\hline $\begin{array}{l}\text { Improving relations with customers } \\
\text { Improving relations with employees } \\
\text { Improving relations with local community } \\
\text { Improving social health of local community } \\
\text { Improving economic health of local community } \\
\text { Improving stakeholder relations in general } \\
\text { Attaining desired profitability } \\
\text { Improving corporate image / reputation } \\
\text { Gaining national and international visibility }\end{array}$ & $\begin{array}{l}3.79 \\
3.55 \\
3.37 \\
3.32 \\
3.30 \\
3.45 \\
3.56 \\
3.67 \\
3.37\end{array}$ & $\begin{array}{l}0.94 \\
1.03 \\
0.89 \\
0.91 \\
0.90 \\
0.91 \\
1.11 \\
0.95 \\
1.03\end{array}$ \\
\hline
\end{tabular}

${ }^{\mathrm{a}}$ Scale used was [min 1; $\left.\max 5\right]$. 
Table 5. Psychometric properties of the measures ${ }^{\mathrm{a}}$

\begin{tabular}{|c|c|c|c|c|}
\hline Measures & Item & Loadings & $\begin{array}{r}\text { Composite } \\
\text { reliability }\end{array}$ & AVE \\
\hline Transaction marketing & $\begin{array}{l}1 \\
2 \\
3 \\
4 \\
5\end{array}$ & $\begin{array}{l}0.70 \\
0.78 \\
0.67 \\
0.79 \\
0.74\end{array}$ & 0.856 & 0.545 \\
\hline Datebase marketing and E-marketing & $\begin{array}{r}1 \\
2 \\
3 \\
4 \\
5 \\
6 \\
7 \\
8 \\
9 \\
10 \\
11 \\
12\end{array}$ & $\begin{array}{l}0.82 \\
0.76 \\
0.78 \\
0.79 \\
0.72 \\
0.71 \\
0.74 \\
0.81 \\
0.76 \\
0.75 \\
0.83 \\
0.80\end{array}$ & 0.947 & 0.600 \\
\hline Interaction marketing & $\begin{array}{l}1 \\
2 \\
3 \\
4 \\
5 \\
6\end{array}$ & $\begin{array}{l}0.77 \\
0.77 \\
0.81 \\
0.77 \\
0.75 \\
0.81\end{array}$ & 0.903 & 0.609 \\
\hline Network marketing & $\begin{array}{l}1 \\
2 \\
3 \\
4 \\
5 \\
6 \\
7 \\
8\end{array}$ & $\begin{array}{l}0.74 \\
0.80 \\
0.80 \\
0.78 \\
0.81 \\
0.72 \\
0.83 \\
0.77\end{array}$ & 0.926 & 0.610 \\
\hline CSR_Employees & $\begin{array}{l}1 \\
2 \\
3 \\
4 \\
5 \\
6\end{array}$ & $\begin{array}{l}0.82 \\
0.85 \\
0.86 \\
0.86 \\
0.88 \\
0.84\end{array}$ & 0.941 & 0.726 \\
\hline CSR_Market (customers and suppliers) & $\begin{array}{l}1 \\
2 \\
3 \\
4 \\
5 \\
6\end{array}$ & $\begin{array}{l}0.84 \\
0.85 \\
0.86 \\
0.89 \\
0.81 \\
0.78\end{array}$ & 0.933 & 0.700 \\
\hline CSR_Environment & $\begin{array}{l}1 \\
2 \\
3 \\
4 \\
5 \\
6\end{array}$ & $\begin{array}{l}0.80 \\
0.89 \\
0.94 \\
0.90 \\
0.89 \\
0.87\end{array}$ & 0.953 & 0.774 \\
\hline CSR_Philanthropy & $\begin{array}{l}1 \\
2 \\
3 \\
4 \\
5 \\
6\end{array}$ & $\begin{array}{l}0.86 \\
0.89 \\
0.89 \\
0.91 \\
0.84 \\
0.86\end{array}$ & 0.951 & 0.765 \\
\hline
\end{tabular}




$\begin{array}{lllll}\text { CSR_Investors } & 1 & 0.93 & 0.962 & 0.895 \\ \text { Performance } & 2 & 0.96 & & \\ & 3 & 0.95 & 0.914 & \\ & 1 & 0.71 & \\ & 2 & 0.75 & \\ & 3 & 0.76 \\ & 4 & 0.78 \\ & 5 & 0.77 \\ & 6 & 0.78 \\ & 7 & 0.66 \\ & 8 & 0.77 \\ & 9 & 0.62\end{array}$

${ }^{\mathrm{a}} \mathrm{AVE}=$ average variance extracted. 
Table 6. Correlations of latent variables ${ }^{\mathrm{a}}$

\begin{tabular}{|c|c|c|c|c|c|c|c|c|c|c|}
\hline & $\begin{array}{l}\text { Transaction } \\
\text { marketing }\end{array}$ & $\begin{array}{l}\text { Database } \\
\text { marketing and } \\
\text { E-marketing }\end{array}$ & $\begin{array}{l}\text { Interaction } \\
\text { marketing }\end{array}$ & $\begin{array}{l}\text { Network } \\
\text { marketing }\end{array}$ & Performance & CSR_Employees & CSR_Market & CSR_Environment & CSR_Philanthropy & CSR_Investors \\
\hline Transaction marketing & 0.738 & & & & & & & & & \\
\hline $\begin{array}{l}\text { Database marketing } \\
\text { and E-marketing }\end{array}$ & 0.480 & 0.775 & & & & & & & & \\
\hline Interaction marketing & 0.477 & 0.381 & 0.780 & & & & & & & \\
\hline Network marketing & 0.498 & 0.723 & 0.586 & 0.781 & & & & & & \\
\hline Performance & 0.279 & 0.365 & 0.330 & 0.415 & 0.736 & & & & & \\
\hline CSR_Employees & 0.340 & 0.310 & 0.486 & 0.414 & 0.448 & 0.852 & & & & \\
\hline CSR_Market & 0.485 & 0.311 & 0.549 & 0.424 & 0.442 & 0.771 & 0.837 & & & \\
\hline CSR_Environment & 0.286 & 0.414 & 0.310 & 0.430 & 0.471 & 0.608 & 0.550 & 0.880 & & \\
\hline CSR_Philanthropy & 0.305 & 0.355 & 0.373 & 0.416 & 0.519 & 0.664 & 0.643 & 0.710 & 0.875 & \\
\hline CSR_Investors & 0.365 & 0.356 & 0.408 & 0.357 & 0.393 & 0.673 & 0.652 & 0.535 & 0.586 & .946 \\
\hline
\end{tabular}

${ }^{a}$ Square root of AVE on diagonal. 
Figure 1. Conceptual framework

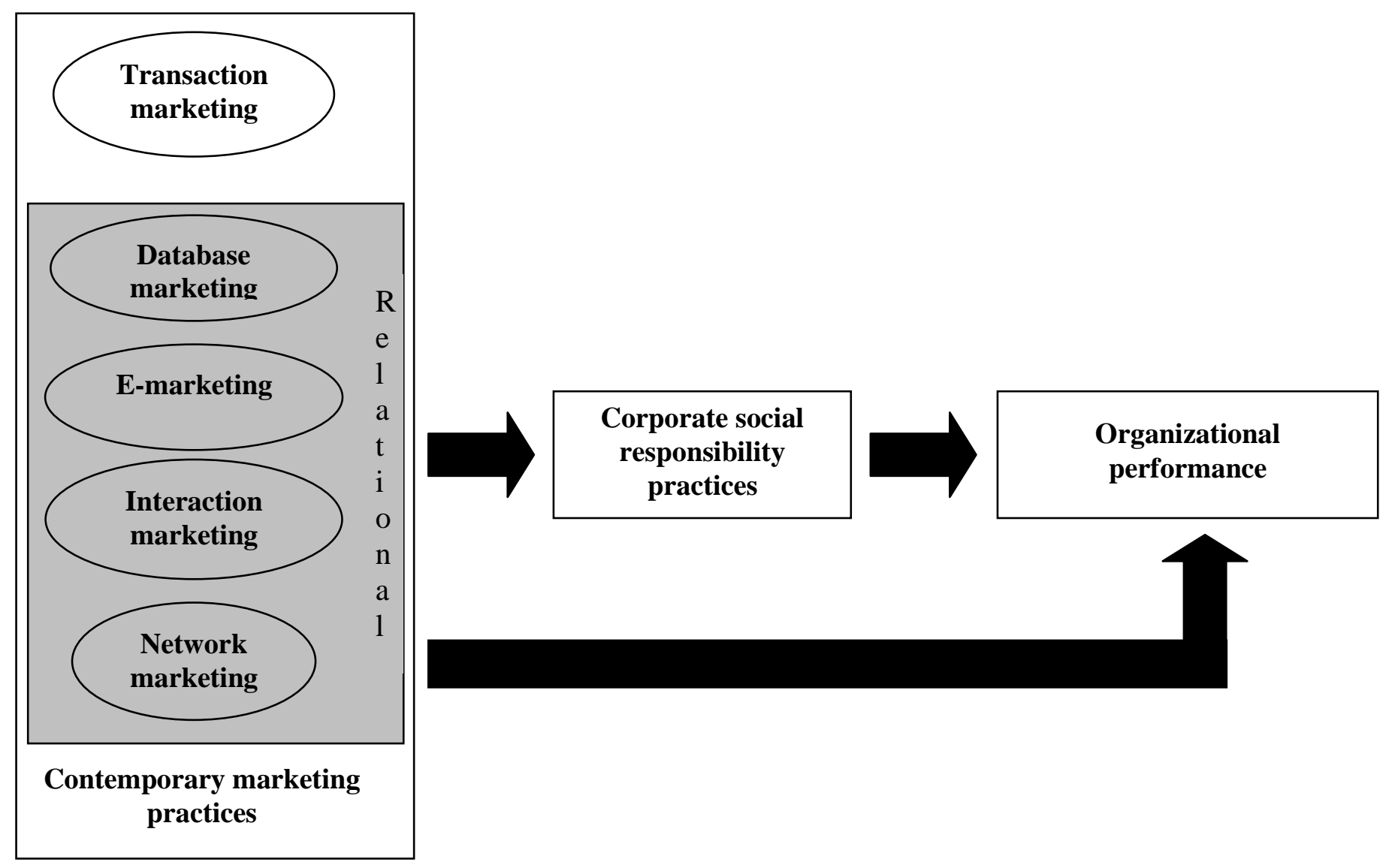




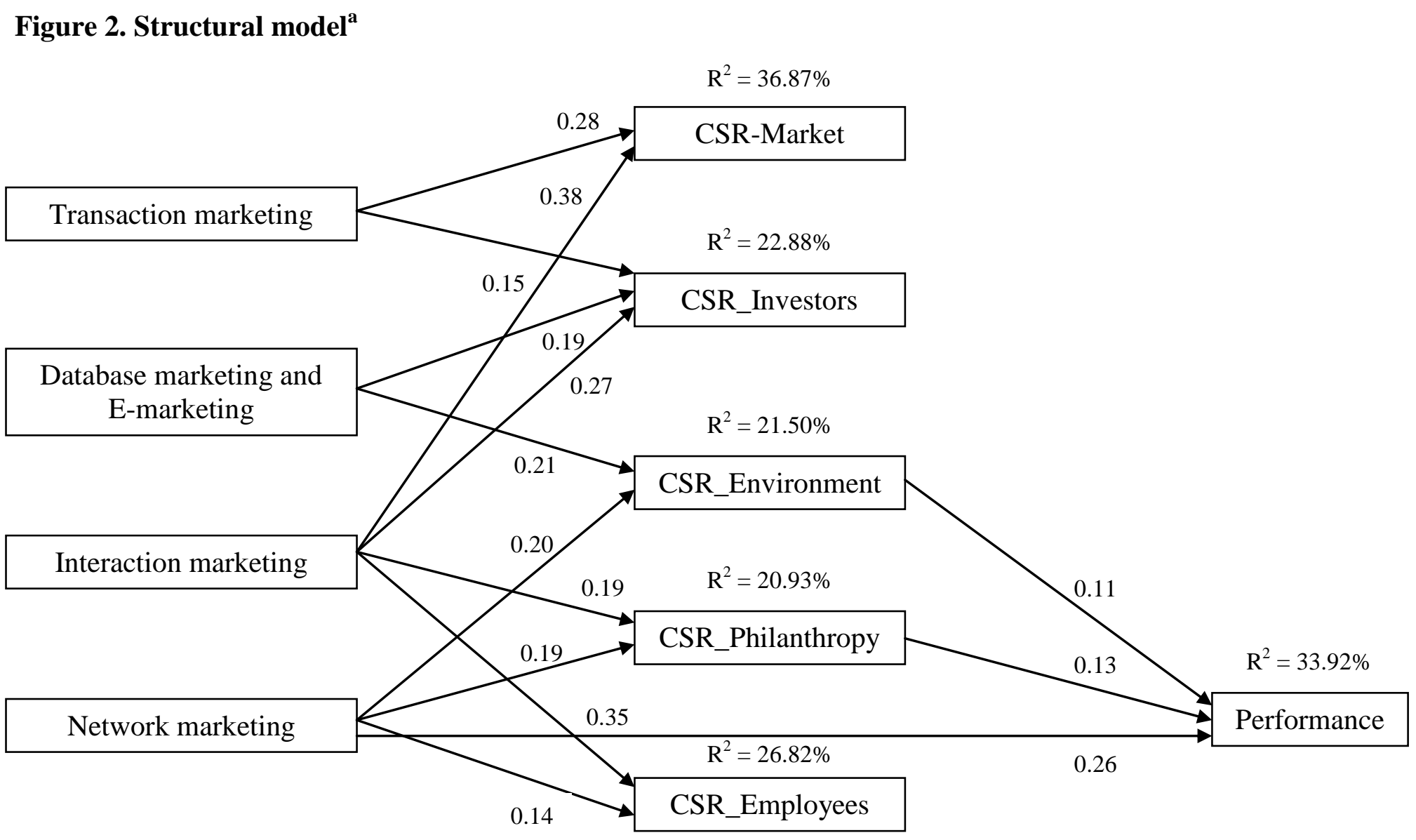

${ }^{a}$ Only significant $(\alpha=0.05)$ standardized path coefficients are depicted. 


\section{BIOGRAPHICAL SKETCHES}

Dr. Adam Lindgreen is Professor of Strategic Marketing at Hull University Business School. He has published in Business Horizons, Industrial Marketing Management, Journal of Advertising, Journal of Business Ethics, Journal of Business and Industrial Marketing, Journal of Marketing Management, Journal of Product and Innovation Management, Journal of the Academy of Marketing Science, and Psychology \& Marketing, among others. Among his books is Managing Market Relationships. His research interests include business and industrial marketing, consumer behavior, experiential marketing, relationship and value management, and corporate social responsibility. He serves on the board of many journals.

Dr. Valérie Swaen works with the Université catholique de Louvain and is also a parttime assistant professor with the IESEG School of Management. Her Ph.D. thesis examines consumer perceptions and reactions to corporate citizenship activities in terms of consumer trust, commitment, and loyalty. She has published in Corporate Reputation Review, Journal of Business Ethics, Recherche et Applications en Marketing, and Revue Française du Marketing, among others.

Dr. Wesley Johnston is Professor of Marketing at Georgia State University. He has published in Journal of Consumer Research, Journal of International Business Studies, Journal of Marketing, and Journal of the Academy of Marketing Science, among others. His research interests include application of behavioral sciences to marketing in the areas of customer relationship management and strategic account programs, as well as network dynamics and relationship strategies, especially in sales force management. 